\title{
Chemical Looping with Copper Oxide as Carrier and Coal as Fuel
}

\author{
E.M. Eyring ', G. Konya' ${ }^{1}$, J.S. Lighty², A.H. Sahir ${ }^{2}$, A.F. Sarofim² and K. Whitty ${ }^{2}$ \\ 1 Department of Chemistry, Institute for Clean and Secure Energy, University of Utah, Salt Lake City, UT 84112 - USA \\ 2 Department of Chemical Engineering, Institute for Clean and Secure Energy, University of Utah, Salt Lake City, UT 84112 - USA \\ e-mail: eyring@chem.utah.edu - konya@chem.utah.edu - jlighty@utah.edu - asad.sahir@utah.edu - sarofim@mit.edu - kevin.whitty@utah.edu
}

\begin{abstract}
Résumé - Boucle chimique pour la combustion du charbon avec un transporteur d'oxygène à base d'oxyde de cuivre - Une analyse préliminaire a été conduite pour estimer les performances d'un procédé en boucle chimique découplé (CLOU, chemical looping uncoupling) pour la combustion du charbon avec un transporteur d'oxygène à base d'oxyde de cuivre. Les avantages de ce système sont démontrés en établissant le bilan énergétique, l'inventaire et le débit de circulation du matériau transportant l'oxygène, les taux de conversion du carbone et la pression partielle en oxygène dans le réacteur de combustion. Pour faire cette analyse, des données expérimentales de cyclage $\mathrm{CuO} / \mathrm{Cu}_{2} \mathrm{O}$ ont été utilisées afin de déterminer les cinétiques de décomposition et d'oxydation du matériau. Elles ont été obtenues avec un oxyde non supporté. La cinétique de décomposition est très rapide à $950^{\circ} \mathrm{C}$ dans les conditions du réacteur de combustion. Il est montré que la cinétique d'oxydation est maximale au voisinage de $800^{\circ} \mathrm{C}$, la vitesse décroissant ensuite pour des températures plus élevées, à cause de résistances diffusionnelles liées à la formation d'une couche de $\mathrm{CuO}$ entourant le $\mathrm{Cu}_{2} \mathrm{O}$. L'analyse montre que le CLOU permet une combustion rapide du carbone, les temps de combustion du carbone étant plus lents que les temps de décomposition du transporteur d'oxygène. Pour confirmer le potentiel du procédé, des données cinétiques additionnelles sont nécessaires sur des oxydes supportés à haute température $\left(>850^{\circ} \mathrm{C}\right)$, dans les conditions du réacteur de combustion permettant la libération d'oxygène par l'oxyde de cuivre.
\end{abstract}

Abstract - Chemical Looping with Copper Oxide as Carrier and Coal as Fuel - A preliminary analysis has been conducted of the performance of a Chemical Looping system with Oxygen Uncoupling (CLOU) with copper oxide as the oxygen carrier and coal approximated by carbon as the fuel. The advantages of oxygen uncoupling are demonstrated by providing the energy balances, the circulation rate of oxygen carrier, the oxygen carrier mass loadings, the carbon burnout and oxygen partial pressure in the fuel reactor. Experimental data on the cycling of cuprous oxide to cupric oxide and kinetics for the oxidation and decomposition reactions of the oxides were obtained for use in the analysis. For this preliminary study unsupported oxides were utilized. The decomposition temperatures were rapid at the high temperature of $950^{\circ} \mathrm{C}$ selected for the fuel reactor. The oxidation kinetics peaked at about $800^{\circ} \mathrm{C}$ with the decrease in rate at higher temperatures, a decrease which is attributed in the literature to the temperature dependence of the diffusional resistance of the $\mathrm{CuO}$ layer surrounding the $\mathrm{Cu}_{2} \mathrm{O}$; the diffusion occurs through grain boundaries in the $\mathrm{CuO}$ layers and the rate of diffusion decreases as a consequence of growth of $\mathrm{CuO}$ grains with increasing temperature. The analysis shows the advantages of CLOU in providing rapid combustion of the carbon with carbon burnout times lower than the decomposition times of the oxygen carrier. For the full potential of CLOU to be established additional data are needed on the kinetics of supported oxides at the high temperatures $\left(>850^{\circ} \mathrm{C}\right)$ at which oxygen is released by the $\mathrm{CuO}$ in the fuel reactor. 


\section{NOTATION}

\section{Symbols}

$\begin{array}{ll}A & \text { Surface area }\left(\mathrm{cm}^{2}\right) \\ d & \text { Diameter of particle }(\mathrm{cm}) \\ D & \text { Diffusion coefficient }\left(\mathrm{cm}^{2} / \mathrm{s}\right) \\ k_{r, \mathrm{C}} & \begin{array}{l}\text { Reaction rate constant for carbon oxidation }\left(\mathrm{g} / \mathrm{cm}^{2}\right. \\ \left.(\text { atm })^{0.5} \mathrm{~s}\right)\end{array} \\ k_{r, \mathrm{Cu}_{2} \mathrm{O}} & \text { Reaction rate constant for CuO reduction }\left(\mathrm{s}^{-1}\right) \\ k_{r, \text { CuO }} & \text { Reaction rate constant for pseudo } \mathrm{Cu}_{2} \mathrm{O} \text { oxidation }\left(\mathrm{s}^{-1}\right) \\ k_{m} & \text { Mass transfer coefficient }(\mathrm{cm} / \mathrm{s}) \\ m & \text { Mass }(\mathrm{g}) \\ N & \text { Moles (mol) } \\ m w & \text { Molecular weight }(-) \\ \rho_{\mathrm{O}_{2}} & \text { Partial pressure of oxygen }(\mathrm{atm}) \\ Q & \text { Heating value }(\mathrm{MJ} / \mathrm{kg}) \\ r & \text { Rate of chemical reaction }(\mathrm{mol} / \mathrm{s}) \\ R & \text { Universal gas constant }\left(\mathrm{cm}^{3} \mathrm{~atm} \mathrm{~mol}^{-1} \mathrm{~K}^{-1}\right) \\ T & \text { Temperature }(\mathrm{K}) \\ V & \text { Volume }\left(\mathrm{cm}^{3}\right) \\ X & \text { Mole ratio }(\text { defined in } E q .1)(-) \\ {[]} & \text { Concentration }\left(\mathrm{mol} / \mathrm{cm}^{3}\right)\end{array}$

\section{Greek Symbols}

$\alpha \quad$ Fractional mass conversion (defined in Eq. 5) (-)

$\lambda \quad$ Parameter (defined in Eq. 15) (-)

$\tau \quad$ Residence time (s)

$\sigma \quad$ Number of particles (-)

$\Delta \quad$ Difference (-)

$\xi \quad$ Conversion (-)

\section{Superscripts}

Rate of circulation $\left(\mathrm{s}^{-1}\right)$

\section{Subscripts}

$\begin{array}{ll}A R & \text { Air Reactor } \\ b & \text { Bulk phase } \\ \mathrm{C} & \text { Carbon } \\ \mathrm{Cu} & \text { Copper } \\ \mathrm{CuO} & \text { Cupric oxide } \\ \mathrm{Cu}_{2} \mathrm{O} & \text { Cuprous oxide } \\ e & \text { Equilibrium } \\ f & \text { Final } \\ F R & \text { Fuel Reactor } \\ i & \text { Initial } \\ \mathrm{O}_{2} & \text { Oxygen } \\ p & \text { Particle } \\ R & \text { Reactor } \\ s & \text { Surface } \\ S & \text { Solids } \\ t & \text { Thermal }\end{array}$

\section{INTRODUCTION}

Chemical Looping Combustion (CLC) shows potential for greatly reducing the energy penalty for carbon capture from coal fired power plants. Very significant progress has been made in the application of CLC to gaseous fuels with pilot units with capacities up to $140 \mathrm{~kW}_{\mathrm{t}}$ having been successfully operated using a variety of oxygen-carriers [1]. The application of CLC to solid fuels, by contrast, has been limited.

The first reference to the application of CLC to solids with the use of $\mathrm{CuO}$ as an oxygen carrier was by Lewis, Gilliland and Sweeney in 1951 [2] for the application to $\mathrm{CO}_{2}$ production without the use of an absorption step. Both hematite ores and supported $\mathrm{CuO}$ were utilized as oxygen-carriers. In this reference and a related patent [3] the importance of the $\mathrm{O}_{2}$ release by $\mathrm{CuO}$ in accelerating the rate of oxidation of solid fuels was recognized. Independently, Mattisson et al. [4] discovered the importance of chemical carriers in Chemical Looping Combustion (CLC) that dissociate to produce oxygen; they designated CLC in which the char gasification occurs by reactions with oxygen as Chemical Looping with Oxygen Uncoupling (CLOU).

In this paper, we shall focus on the application of CLOU involving $\mathrm{CuO}$ as the oxidant and $\mathrm{C}$ as the reactant to accelerate the slow step of gasifying the char in conventional CLC. For this case, the relevant reactions in the fuel reactor are the endothermic dissociation $4 \mathrm{CuO}=2 \mathrm{Cu}_{2} \mathrm{O}+\mathrm{O}_{2}$ and the exothermic oxidation $\mathrm{C}+\mathrm{O}_{2}=\mathrm{CO}_{2}$ to provide an overall exothermic reaction $4 \mathrm{CuO}+\mathrm{C}=2 \mathrm{Cu}_{2} \mathrm{O}+\mathrm{CO}_{2}$ [4]. The reduced $\mathrm{CuO}$ from the fuel reactor is transported to the air reactor where it is reoxidized and then recycled to the fuel reactor. The current study provides an assessment of this process with emphasis on quantifying the role of oxygen uncoupling in accelerating gasification of carbonaceous fuels, here simply represented by carbon.

The results of [2] will be used to illustrate the augmentation of the $\mathrm{C}$ gasification reaction by the oxygen liberated by $\mathrm{CuO}$. In Reference 2, the reactions of the $\mathrm{CO}_{2}$ gasification kinetics in a batch fluidized-bed reactor in which the dried product gases (mainly $\mathrm{CO}_{2}$ ) were recycled where either (1) 40-200 mesh (75-420 $\mu \mathrm{m})$ hematitic ore was reduced with a coke (97.8\% $\mathrm{C}$ on ash-free basis), or (2) $\mathrm{CuO}$ supported on 20-200 mesh $(75-850 \mu \mathrm{m})$ silica gel was used as the oxygen carrier. The reactor was maintained at constant temperature and pressure. The oxygen carrier was introduced to the reactor which was purged with $\mathrm{CO}_{2}$ prior to introduction of the coke. For the case of the $\mathrm{CuO}$ oxygen carrier, the composition of the recirculating gases, recirculated at a rate sufficient to maintain a superficial velocity of $23.6 \mathrm{~cm} / \mathrm{s}$, was measured prior to the introduction of coke to obtain the equilibrium partial pressure of $\mathrm{O}_{2}$. A run was initiated by charging and fluidizing a batch of oxygen carrier. After the temperature and pressure had stabilized a known amount of 100-140 mesh $(104-152 \mu \mathrm{m})$ metallurgical coke was introduced. 
During a run the rates of hematite or $\mathrm{CuO}$ reduction and coke gasification were followed by carbon and oxygen material balances on samples withdrawn from the bed at short time intervals. The gas composition was also monitored for $\mathrm{CO}_{2}$ and the sum of $\mathrm{O}_{2}$ and $\mathrm{CO}$ (predominantly $\mathrm{O}_{2}$ in the early stages and $\mathrm{CO}$ in the late stages).

From runs at $900^{\circ} \mathrm{C}, 950^{\circ} \mathrm{C}, 1000^{\circ} \mathrm{C}$, and $1050^{\circ} \mathrm{C}$, the rate of the $\mathrm{C}+\mathrm{CO}_{2}$ reaction rate was determined and correlated. These results can be used to determine the augmentation of the carbon gasification rate for the case of the $\mathrm{CuO}$ carrier when the $\mathrm{C}+\mathrm{CO}_{2}$ and $\mathrm{C}+\mathrm{O}_{2}$ reactions occur in parallel. For the $\mathrm{CuO}$ run (CC-6 in [2]) at a temperature of $955 \pm 5^{\circ} \mathrm{C}$ and pressure of 1.095 atmosphere, the initial charge contained 1141 milli-gram moles of $\mathrm{CuO}$ and 1039 milli-gram atoms of C. The initial oxygen concentration fell to $0.133 \%$ in 240 seconds during which over $40 \%$ of the $\mathrm{CuO}$ had decomposed. The oxygen concentration remained around this value for more than 2000 additional seconds with an approximate constant rate of reaction of $8.3 \times 10^{-5} \mathrm{~s}^{-1}$ (i.e. $8.3 \times 10^{-5}$ atoms $\mathrm{C}$ gasified per second per atom carbon in bed) until the $\mathrm{O} / \mathrm{C}$ ratio reached 0.5 (corresponding to $\mathrm{Cu}_{2} \mathrm{O}$ ). The $0.13 \% \mathrm{O}_{2}$ increased the rate of carbon gasification over that expected from that of the $\mathrm{CO}_{2}$ (over $99 \%$ of the gas concentration) by a factor of 2.56. The $\mathrm{O}_{2}$ concentration and the ratio of the gasification by $\mathrm{O}_{2}$ divided by that due to $\mathrm{CO}_{2}$ is summarized in Figure 1, showing a maximum increase in rate for the $\mathrm{CuO}$ oxygen carrier over that observed for the hematite by a factor of about 60 . The oxygen partial pressure at the start of the run $(\mathrm{O} / \mathrm{Cu}=1)$ was initially at the equilibrium value of $4.5 \%$ and decreases as the $\mathrm{O} / \mathrm{Cu}$ decreases as the run progresses. Analysis of the results for runs made with a $\mathrm{CuO}$ oxygen carrier at $845^{\circ} \mathrm{C}$ and $890^{\circ} \mathrm{C}$ showed maximum increases in rate

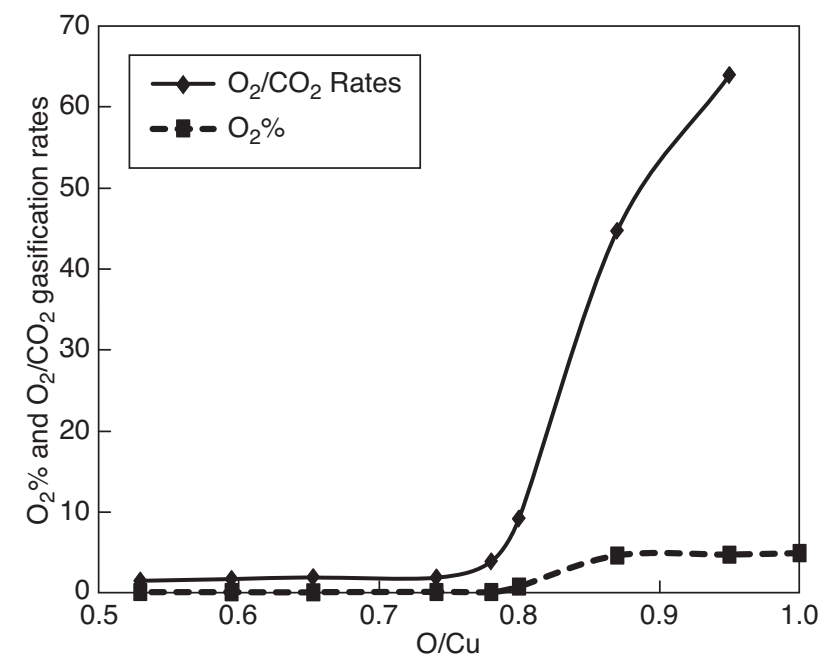

Figure 1

Enhancement in gasification rates by using copper oxide as an oxygen carrier based on results of Lewis et al. [2]. over those for the $\mathrm{C}+\mathrm{CO}_{2}$ reactions at equal temperatures of 24 and 32, respectively. The advantage of CLOU is these high increases in carbon gasification rate. It is noteworthy that a 50 fold increase in reaction rate when burning a Mexican petroleum coke with $\mathrm{CuO}$ oxygen carrier at temperatures $\left(950^{\circ} \mathrm{C}\right.$ to $\left.985^{\circ} \mathrm{C}\right)$ where $\mathrm{CLOU}$ prevailed relative to the rate for CLC with an iron-based carrier was reported [4], an increase comparable to that reported in [2].

The major advantage of CLOU is the large reduction in the time needed to convert solid carbon in the fuel reactor, a property especially important for low reactivity fuels. In studies of CLC and CLOU in a batch reactor [4-8] it was determined that, for a low reactivity solid, such as petroleum coke, the times for reaction of the coke with $\mathrm{CO}_{2}$ was impractically long (50 minutes to reach $95 \%$ conversion at $950^{\circ} \mathrm{C}$ for the injection of $0.2 \mathrm{~g}$ of coke in $20 \mathrm{~g}$ of fluidized carrier composed of $60 \% \mathrm{Fe}_{2} \mathrm{O}_{3}$ and $40 \% \mathrm{MgAl}_{2} \mathrm{O}_{4}$, compared to 8 minutes when steam was added to produce an atmosphere of $\left.50 \% \mathrm{H}_{2} \mathrm{O}[6]\right)$. These times can be compared with a time of $30 \mathrm{~s}$ required to react $0.1 \mathrm{~g}$ of petroleum coke completely in $15 \mathrm{~g}$ of fluidized $\mathrm{CuO} / \mathrm{ZrO}_{2}$ at $955^{\circ} \mathrm{C} \mathrm{[5].} \mathrm{The} \mathrm{reduced} \mathrm{reac-}$ tion times for carbon achievable with CLOU will result in reductions in the size for the fuel reactor and the total amount of oxygen carrier.

A second advantage of CLOU relative to CLC is that the reactions in both the fuel and air reactors are exothermic. The circulation rate of the oxygen carrier can therefore be determined solely on the basis of providing the oxygen to the fuel in the air reactor, in distinction to CLC reactors where the circulation rate is determined by the need to transfer energy from the air reactor to supply the endothermic reactions in the fuel reactor.

A third advantage is that the fuel reactor is overall oxidizing so that sulfur compounds released by high sulfur fuels will be in the form primarily of $\mathrm{SO}_{2}$. This has the advantage of eliminating problems with sulphide formation by the oxygen carrier. The formation of $\mathrm{CuSO}_{4}$ is also not favored thermodynamically with unrealistically high concentrations of $\mathrm{SO}_{x}$, in excess of $30000 \mathrm{ppm}$, required to form the sulfate at $600^{\circ} \mathrm{C}$ and the concentration needed increase rapidly as temperature is increased [7].

A comprehensive study of the reaction of copper-based oxygen-carriers with syngas and methane fuels has been conducted with definitive studies on the: preparation and characterization of oxygen-carriers [9-13] with different substrates $\left(\mathrm{Al}_{2} \mathrm{O}_{3}, \mathrm{SiO}_{2}, \mathrm{TiO}_{2}\right.$ and yttrium stabilized zirconia); chemical kinetics of the oxidation and reduction of the oxygen-carriers at both atmospheric and elevated pressures [9, 13-14]; development of design criteria [13, 15], including detailed maps for the circulation of the oxygen carrier and the weight of oxygen carrier as functions of different oxygen carrier conversions in the fuel and air reactors, and oxygen carrier reactivity; the successful operation of a $500 \mathrm{~W}_{\mathrm{t}}[16]$ 
and $10 \mathrm{~kW}_{\mathrm{t}}[17,18]$ CLC system of two interconnected fluidized beds; development of a detailed mechanistic model [19] of the CLC system and validation with data from the $10 \mathrm{~kW}_{\mathrm{t}}$ unit; the reclamation of copper from spent oxygen carrier [20]. These studies have shown that copper oxide based carriers have great potential because of their high reactivity and resolved questions that had been raised on attrition, agglomeration, and sulfur contamination. Furthermore, preliminary analysis showed the economic viability of the copper oxide based oxygen-carriers [15].

The study of the use of copper oxide carriers for the combustion of solid fuels has by comparison received little attention. Reference has been already made of the early studies of oxygen uncoupling $[2,3]$ which were largely forgotten until the independent discovery of CLOU [4]. $\mathrm{ZrO}_{2}$ supported $\mathrm{CuO}$ was utilized [4] as the oxygen carrier and the system was operated at temperatures high enough to produce a significant partial pressure of oxygen to react with solid carbon (equilibrium $\mathrm{O}_{2}$ partial pressure for $\mathrm{CuO} / \mathrm{Cu}_{2} \mathrm{O}>0.005 \mathrm{~atm}$ for $T>850^{\circ} \mathrm{C}$ ). Small batches of fuel were added to a laboratory electrically heated fluidized bed reactor with the gas concentration cycled from oxidizing to inert. The times for conversion of a Mexican petroleum coke ranged from about $127 \mathrm{~s}$ at a set temperature of $885^{\circ} \mathrm{C}$ (bed temperatures were slightly higher due to the exothermic reactions) to about $14 \mathrm{~s}$ at a set temperature of $985^{\circ} \mathrm{C}$ [4]. The times to reoxidize the $\mathrm{Cu}_{2} \mathrm{O}$ were also fast although not quantified in the publication. These studies were extended to the combustion of a lignite (Lausitz, Germany) which reacted in times of 30 to $45 \mathrm{~s}$ in the temperature range of 850 to $985^{\circ} \mathrm{C}$ [7]. Other CLC applications of copper carriers with solid fuels involve:

- the study of the reaction of two bituminous coals (Taldinskaya, Russia and US Illinois No. 5, USA) and a lignite (Hambach, Germany) in a batch fluidized bed reactor with cycling of gas composition and of the oxygen carrier between $\mathrm{Cu}$ and $\mathrm{Cu}_{2} \mathrm{O}$ has been reported for a reactor temperature of $930^{\circ} \mathrm{C}$, with high rates of reaction observed for the lignite but incomplete combustion of the bituminous coals [21], and;

- a TGA study of packed carbonaceous fuels and $\mathrm{CuO}$ that demonstrated very fast reactions at relatively low temperatures of 500 to $700^{\circ} \mathrm{C}$ apparently as a consequence of solid-solid reactions [22, 23].

\section{DESIGN CRITERIA}

The objective of the present work is to develop design criteria for a Chemical Looping with Oxygen Uncoupling (CLOU) process, providing order of magnitude estimates of:

- the temperatures of the fuel and air reactors (Sect. 4);

- the rate of circulation of the oxygen carrier (Sect. 2);

- the total oxygen carrier loading (Sect.4);

- the carbon loading and oxygen partial pressure in the fuel reactor (Sect. 5).
As an initial step, an ASPEN PLUS Simulation was developed to determine the requisite energy and material flows, incorporating the following assumptions:

- the solid fuel has been assumed to consist of pure carbon for simplicity of order of magnitude analysis. This eliminates complications associated with the combustion of the volatiles that would be released by most solid fuels. The emphasis on carbon is motivated by the fact that carbon gasification has been shown to be the limiting factor in the combustion of coals and petroleum cokes [2-8] and significant progress has been made in developing CLC for gaseous compounds representative of volatiles;

- the flow in the fuel and air reactors is approximated by simple plug flow reactors. This leaves the final design of the CLC system open. Most of the laboratory and pilot demonstrations have utilized fluidized bed designs, but other configurations involving moving beds [24], or multiple interconnected moving or fluidized beds [3, 26, 27] have been used or proposed.

The fuel and the air reactors have been modeled using the RSTOIC Reactor model in ASPEN PLUS. The reactions occurring in the fuel reactor are $\mathrm{CuO}$ decomposition to yield oxygen, (by $4 \mathrm{CuO} \rightarrow 2 \mathrm{Cu}_{2} \mathrm{O}+\mathrm{O}_{2}$ ), and the oxidation of char particles, $\left(\mathrm{C}+\mathrm{O}_{2}\right)$. The $\mathrm{CuO}$ is regenerated in the air reactor by the reaction: $2 \mathrm{Cu}_{2} \mathrm{O}+\mathrm{O}_{2} \rightarrow 4 \mathrm{CuO}$. The $\mathrm{O}_{2}$ concentration in the effluent of the air reactor is set at $3 \%$ consistent with that in coal-fired utility boilers.

The results of the ASPEN simulations are presented in Figure 2. The material and energy balance has been developed assuming a flow of $100 \mathrm{~kg} / \mathrm{h}$ of carbon feed, with a mole conversion of $60 \%$ of $\mathrm{CuO}$ in the fuel reactor and $64 \%$ of $\mathrm{Cu}_{2} \mathrm{O}$ in the air reactor (justification for which shall be presented in Sect. 4). For these conversions, and the temperatures and oxygen carrier circulation rates indicated in Figure 2, the energy release is $357 \mathrm{~kW}$ in the fuel reactor and $574 \mathrm{~kW}$ in the air reactor, distinctively different from the operation of a CLC where the fuel reactor operation is normally endothermic. The reason, as mentioned previously, is that the overall reaction in the fuel reactor, $4 \mathrm{CuO}+\mathrm{C} \rightarrow 2 \mathrm{Cu}_{2} \mathrm{O}+\mathrm{CO}_{2}$, is exothermic.

\section{OXYGEN-CARRIER CIRCULATION RATE}

The circulation rate of the oxygen carrier, together with the total mass of oxygen-carrier, is recognized to be instrumental in the economical design of a chemical looping system [5, $13,15,27]$. For oxygen uncoupling, as mentioned above, the circulation rate is governed by the need to supply the fuel reactor with the oxygen needed to consume the fuel. The analysis that follows assumes complete fuel consumption, an assumption that will be justified in Section 5. The moles (or mass) of $\mathrm{Cu}$ circulating between the fuel and air reactor has been chosen as the basis for calculation here, as it is 


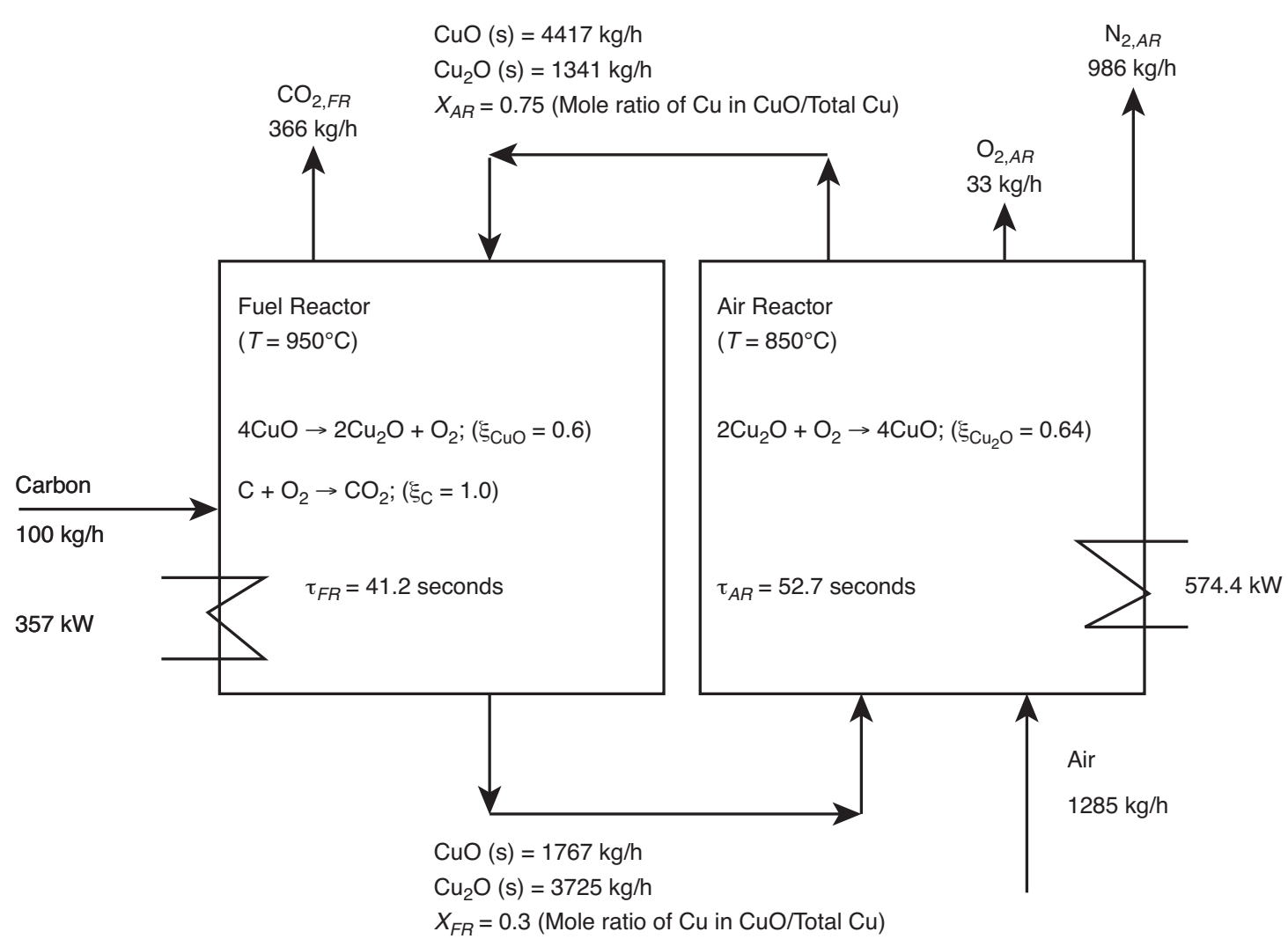

Figure 2

ASPEN simulation of material and energy balances in an idealized CLOU process with $100 \mathrm{~kg} / \mathrm{h}$ carbon feed.

independent of the oxygen state of the oxygen-carrier. The calculations are based on the mole fraction of copper in the oxygen-carrier:

$$
X_{\mathrm{CuO}}=\frac{\dot{N}_{\mathrm{CuO}}}{\dot{N}_{\mathrm{CuO}}+2 \dot{N}_{\mathrm{Cu}_{2} \mathrm{O}}}=\frac{\dot{N}_{\mathrm{CuO}}}{\dot{N}_{\mathrm{Cu}}}
$$

where, $\dot{N}_{\mathrm{CuO}}, \dot{N}_{\mathrm{Cu}_{2} \mathrm{O}}$, and $\dot{N}_{\mathrm{Cu}}$ are the molar flow rates of $\mathrm{CuO}$, $\mathrm{Cu}_{2} \mathrm{O}$, and $\mathrm{Cu}$, respectively. For the fuel reactor, the difference in the oxygen in the oxygen-carrier entering and leaving the reactor is consumed in the combustion of carbon fuel. For a stoichiometric equation of $4 \mathrm{CuO}+\mathrm{C}=2 \mathrm{Cu}_{2} \mathrm{O}+\mathrm{CO}_{2}$, the following relation therefore exists between the molar rate of carbon feed $\dot{N}_{C}$ and the difference in flow of $\dot{N}_{\text {CuO }}$, entering and leaving the reactor:

$$
\dot{N}_{\mathrm{C}}=\frac{\dot{N}_{\mathrm{Cu}}\left(X_{\mathrm{CuO}, A R}-X_{\mathrm{CuO}, F R}\right)}{4}
$$

where $A R$ and $F R$ refer to Air and Fuel Reactor, respectively. Rearrangement yields:

$$
\frac{\dot{N}_{\mathrm{Cu}}}{\dot{N}_{\mathrm{C}}}=\frac{4}{\left(X_{\mathrm{CuO}, A R}-X_{\mathrm{CuO}, F R}\right)}
$$

The difference in mole ratio $X_{\mathrm{CuO}}$ at the exit of the Air and Fuel Reactors is defined as $\Delta X_{S}=\left(X_{\mathrm{CuO}, A R}-X_{\mathrm{CuO}, F R}\right)$.

Equation (4) can be used to determine the proportionality between the energy in the fuel introduced to the fuel reactor in megawatts of thermal energy and the mass flow rate of $\mathrm{Cu}$ circulating in the system, $\dot{m}_{\mathrm{Cu}}$ :

$$
\dot{m}_{\mathrm{Cu}}=\frac{4\left(m w_{\mathrm{Cu}}\right)}{\Delta X_{S}\left(m w_{\mathrm{C}}\right) Q_{C}}
$$

This relation is shown in Figure 3 in which the mass of copper circulated in the system per $\mathrm{MW}_{\mathrm{t}}$ of carbon introduced in the fuel reactor is plotted versus the difference in mole ratio $\Delta X_{S}$ for different values of $X_{\mathrm{CuO}, F R}$ (Fig. 3). It should be noted that the circulation mass in Figure 3 needs to be corrected for both oxidation of the $\mathrm{Cu}$ (increases of a factor of 1.13 to 1.25 depending on the oxidation state of the $\mathrm{Cu}$ ) and on the percent of copper loading on the oxygencarrier when calculating the total mass of oxygen carrier. Supported oxygen-carriers with $\mathrm{CuO}$ loadings of up to $80 \%$ have been prepared with binders (substrates) of $\mathrm{Al}_{2} \mathrm{O}_{3}$, Sepiolite, $\mathrm{SiO}_{2}, \mathrm{TiO}_{2}$, and $\mathrm{ZrO}_{2}$ [9]. However, studies of agglomeration of $\mathrm{Al}_{2} \mathrm{O}_{3}$-supported oxygen-carriers suggested 


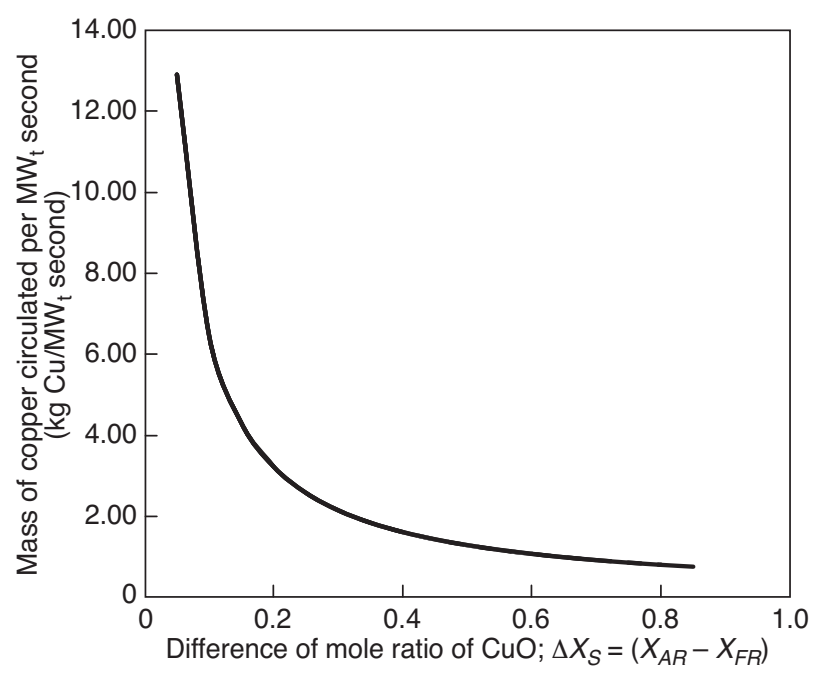

Figure 3

Variation in mass $(\mathrm{kg})$ of copper circulated per $\mathrm{MW}_{\mathrm{t}} \mathrm{s}$ with variation in difference of $\mathrm{CuO}$ mole ratio.

that the $\mathrm{CuO}$ loadings should not exceed $20 \%$ in order to prevent agglomeration. Operation of a $10 \mathrm{~kW}_{\mathrm{t}}$ chemical looping combustor with a $\mathrm{CuO}$ initial concentration of $14 \%$ with an $\mathrm{Al}_{2} \mathrm{O}_{3}$ substrate stabilized at a loading of about $10 \% \mathrm{CuO}$ after $100 \mathrm{~h}$ of operation. In order to compare oxygen-carrier rates on a common basis the rates will be converted to the rates of $\mathrm{CuO}$ circulated on a support free basis.

The rates of circulation for CLOU are compared with selected values in the literature assuming that the value of $\Delta X_{S}$ is about 0.45 (see Fig. 2), to be justified later. Given the results of Figure 3, a circulation of approximately 1.8 $\mathrm{kg} /(\mathrm{s})\left(\mathrm{MW}_{\mathrm{t}}\right)$ is required on a support-free basis. The total rate of material circulated is equal to this value divided by the weight percent of $\mathrm{CuO}$ for oxygen carriers consisting of supported $\mathrm{CuO}$. In order to compare the present result with results reported in the literature the data in the literature need to be converted to a support-free basis by multiplying the reported rates by the weight percent of active material on the supported oxygen carrier. On a support-free basis, the circulation rate of $1.8 \mathrm{~kg} /(\mathrm{s})\left(\mathrm{MW}_{\mathrm{t}}\right)$ are comparable to values reported in the literature of $2 \mathrm{~kg} \mathrm{CuO} /(\mathrm{s})\left(\mathrm{MW}_{\mathrm{t}}\right)$ (at $\left.\Delta X_{S}=0.4\right)$ for the combustion of petroleum coke using CLOU [5] and $1 \mathrm{~kg} \mathrm{CuO/(s)}\left(\mathrm{MW}_{\mathrm{t}}\right)$ for a fuel gas [15].

\section{KINETICS OF OXIDATION AND REDUCTION OF OXYGEN CARRIER}

The masses of oxygen-carrier in the fuel and air reactors can be estimated from the products of the oxygen-carrier circulation rate and the time to reduce the $\mathrm{CuO}$ for the fuel reactor and the time to oxidize the resultant $\mathrm{Cu}_{2} \mathrm{O}$ in the air reactor. This section describes the determination of the chemical kinetics of oxidation and reduction of the oxygen carrier that are needed for such an analysis. For the present order-ofmagnitude analysis, the kinetics were determined for unsupported copper oxide; later studies are planned with supported catalysts.

The kinetics were determined using two TGAs, a TA Q500 and a TA Q600. Quartz sample pans were used. The gas flows for the TA Q500 was $40 \mathrm{~mL} / \mathrm{min}$ to the balance arm and $60 \mathrm{~mL} / \mathrm{min}$ to the sample. Samples of $\mathrm{CuO}$ powder from Johnson Matthey Chemicals in the size range of 1-10 $\mu \mathrm{m}$ were used for most of the runs. The BET surface area of the initial sample was in the range of 0.22 to $0.27 \mathrm{~m}^{2} / \mathrm{g}$, which corresponds to a mean diameter of about $4 \mu \mathrm{m}$. Runs were conducted by introducing samples of about $20 \mathrm{mg}$ into the TGA at ambient temperature and pressure. The TGA was heated to the reaction temperature in nitrogen and then the gas through the reactor was cycled between nitrogen and air, with a rapid switching of the gases. After an initial transient of 6 cycles a steady cycling was observed.

In order to provide time to purge the gases from the TGA between cycles and to achieve complete oxidation, the cycle times were 30 minutes for air and 40 minutes for nitrogen. The results of 33 cycles are shown in Figure 4 for runs conducted isothermally at $850^{\circ} \mathrm{C}$. The difference between the asymptotic weights during oxidation and reduction is in good agreement with the mass difference between $\mathrm{Cu}_{2} \mathrm{O}$ and $\mathrm{CuO}$ : $\left(2 \mathrm{CuO}-\mathrm{Cu}_{2} \mathrm{O}\right) /(2 \mathrm{CuO})=0.1006$. The explanation for the high conversion of the unsupported $\mathrm{CuO}$ and $\mathrm{Cu}_{2} \mathrm{O}$ during cycling is that the particles swell and develop porosity during reaction, as determined from electron micrographs of the samples before and after sampling and from an increase in BET surface area from an original value of $0.2 \mathrm{~m}^{2} / \mathrm{g}$ to $0.8 \mathrm{~m}^{2} / \mathrm{g}$ after 20 cycles [28]. The particles sintered at the higher temperatures but continued to show high reactivity and ability to cycle. The sintering is expected from the low Tammann temperatures (equal to half the absolute temperature of melting) for $\mathrm{CuO}$ and $\mathrm{Cu}_{2} \mathrm{O}$ of $526^{\circ} \mathrm{C}$ and $481^{\circ} \mathrm{C}$, respectively. Although the mobility of the oxides at low temperatures is responsible for sintering and excludes the use of the unsupported oxides, the mobility is beneficial in providing good coverage for supported oxides.

The results of a single cycle at temperatures of $850^{\circ} \mathrm{C}$ and $950^{\circ} \mathrm{C}$ are presented in Figures 5 and 6 . The fast rise and decline in the mass traces in Figures 5 and 6 occur at the times of changes in gas concentration. In Figure 5, the decline in the mass corresponds to the decomposition of $\mathrm{CuO}$ in a $\mathrm{N}_{2}$ environment at $850^{\circ} \mathrm{C}$. When the $\mathrm{N}_{2}$ is switched to air, the increase in mass corresponds to the oxidation of the $\mathrm{Cu}_{2} \mathrm{O}$. Reaction goes to completion for both decomposition and oxidation. The slope for the oxidation is steeper than that for decomposition indicating a faster rate of oxidation of $\mathrm{Cu}_{2} \mathrm{O}$ than decomposition of $\mathrm{CuO}$. Conversely, at $950^{\circ} \mathrm{C}$ 


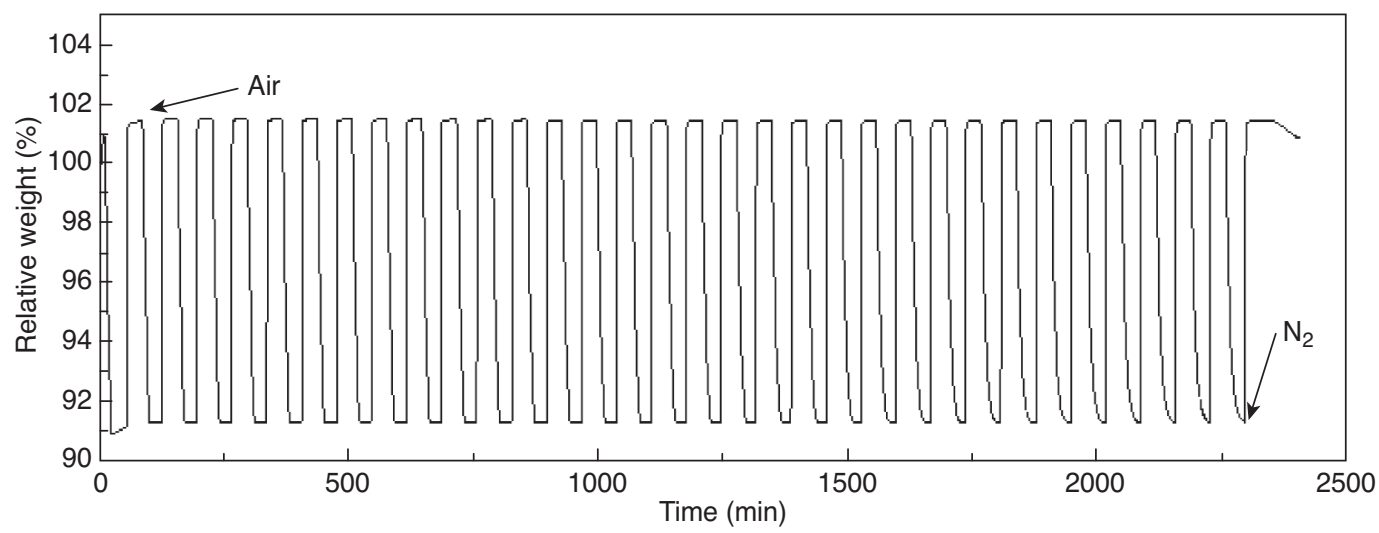

Figure 4

Results of Chemical Looping with Oxygen Uncoupling experiments (between $\mathrm{CuO}$ and $\mathrm{Cu}_{2} \mathrm{O}$ ) conducted at $850^{\circ} \mathrm{C}$ for 33 cycles with a cycle time of 30 minutes for air and 40 minutes for $\mathrm{N}_{2}$.

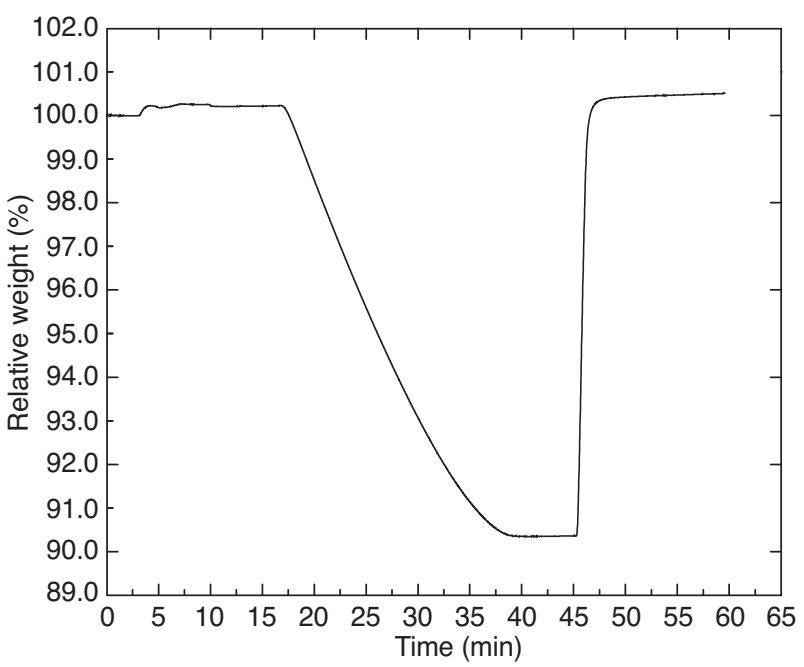

Figure 5

Chemical Looping with Oxygen Uncoupling results with copper oxide at $850^{\circ} \mathrm{C}$ for a single cycle.

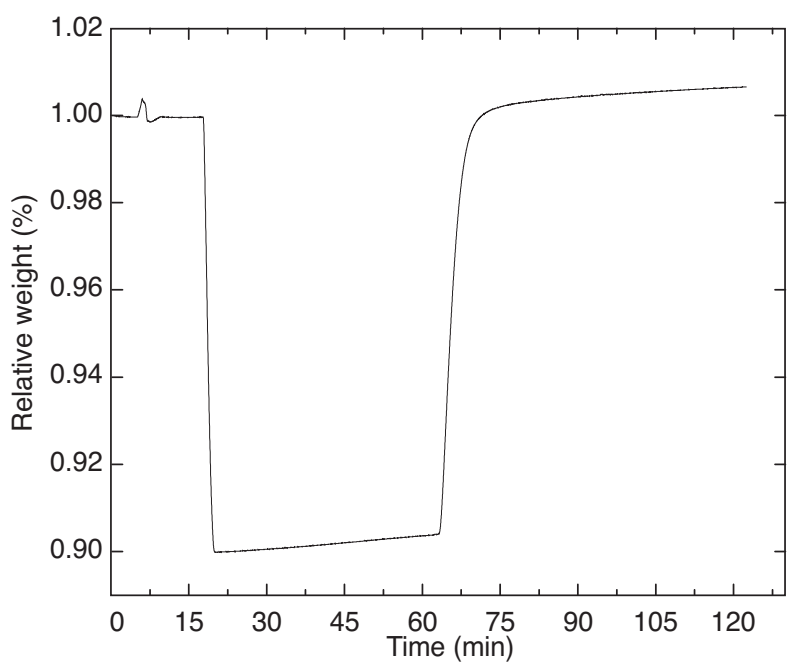

Figure 6

Chemical Looping with Oxygen Uncoupling results with copper oxide at $950^{\circ} \mathrm{C}$ for a single cycle.
(Fig. 6) the decomposition of $\mathrm{CuO}$ is faster than the oxidation of the $\mathrm{Cu}_{2} \mathrm{O}$. The individual cycles were studied to obtain reaction kinetics. The fractional mass conversion, $\alpha$, is defined as:

$$
\alpha=\frac{m-m_{i}}{m_{f}-m_{i}}
$$

where $m$ is the transient mass, $m_{i}$ the initial mass at the start of a run, and $m_{f}$ the final mass at the end of a run. The data for the decomposition of $\mathrm{CuO}$ at 850,900 , and $950^{\circ} \mathrm{C}$ are shown in Figure 7 together with an empirical first order fit developed for purposes of modelling. The adequacy of the first order fit decreases with increasing temperature, as has been observed by other investigators $[9,28]$. The corresponding curves for oxidation of $\mathrm{Cu}_{2} \mathrm{O}$ in air are shown in Figure 8. The oxidation curves show a decrease in reaction rate at high temperature.

The kinetic rate constants are plotted versus temperature in Figure 9. The decomposition of $\mathrm{CuO}$ can be described by an Arrhenius expression with an activation energy of $327 \mathrm{~kJ} / \mathrm{mol}$. Above $800^{\circ} \mathrm{C}$, oxidation of $\mathrm{Cu}_{2} \mathrm{O}$ shows a progressive decrease in rate with increasing temperature. This unusual behaviour has been observed previously for the oxidation of copper [29] and cuprous oxide [30]. These references underline the complexity of the mechanism of 


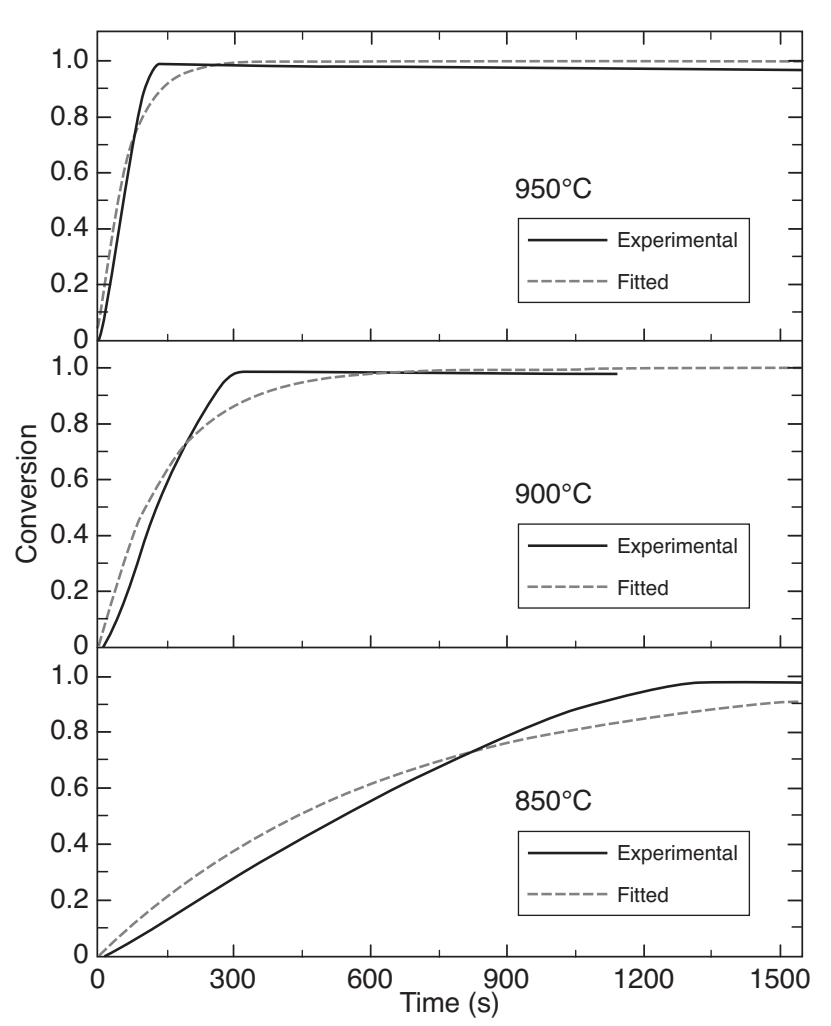

Figure 7

Reduction of cupric oxide $v s$ time at temperatures of 850,900 and $950^{\circ} \mathrm{C}$. Solid lines represent experimental data; dashed lines first order fits to the data.

oxidation of copper and cuprous oxide. Relevant to the current study is the observation that the oxidation rate is controlled by the diffusion through the $\mathrm{CuO}$ layer engulfing the $\mathrm{Cu}_{2} \mathrm{O}$. Since bulk diffusion through the $\mathrm{CuO}$ is slow, the rate is controlled by the diffusion through grain boundaries in the $\mathrm{CuO}$. As temperature increases, the grains grow rapidly, reducing the rate of increase in oxidation [29] and even leading to a decrease in rate [30]. A further complication is provided by the changes in surface areas resulting from the changes in porosity governed in part by the difference in molar volumes of $\mathrm{CuO}$ and $\mathrm{Cu}_{2} \mathrm{O}$. Clearly the order of the reaction will be complicated by the complex mechanism involving kinetics, multiple diffusional steps, and changing surface area. The first order representation of the data was purely for ease of analysis and no mechanistic implication is implied nor is the first order fit the best representation of the data (an AvramiErofeev expression gives a better fit of the data).

The rates found in this study for the decomposition of $\mathrm{CuO}$ and oxidation of $\mathrm{Cu}_{2} \mathrm{O}$ have been compared with data in the literature. The results compare well with those obtained in the study of Chadda et al. [28] for the decomposition rate

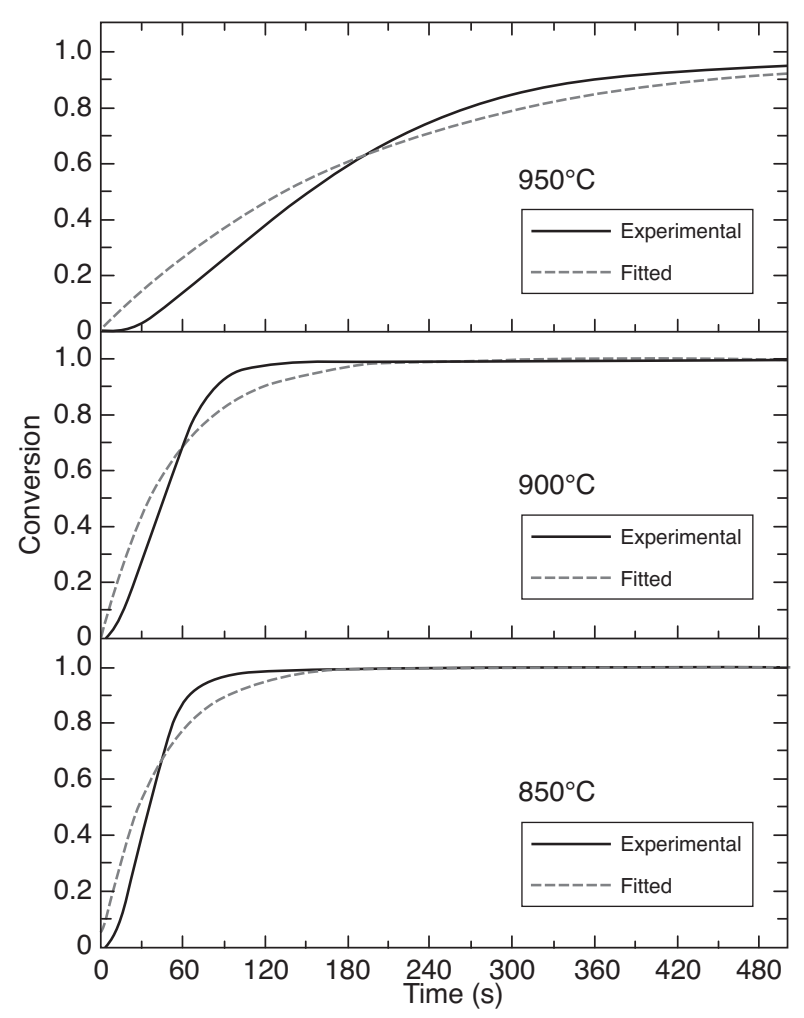

Figure 8

Oxidation of cuprous oxide $v s$ time at temperatures of 850 , 900 and $950^{\circ} \mathrm{C}$. Solid lines represent experimental data; dashed lines first order fits to the data.

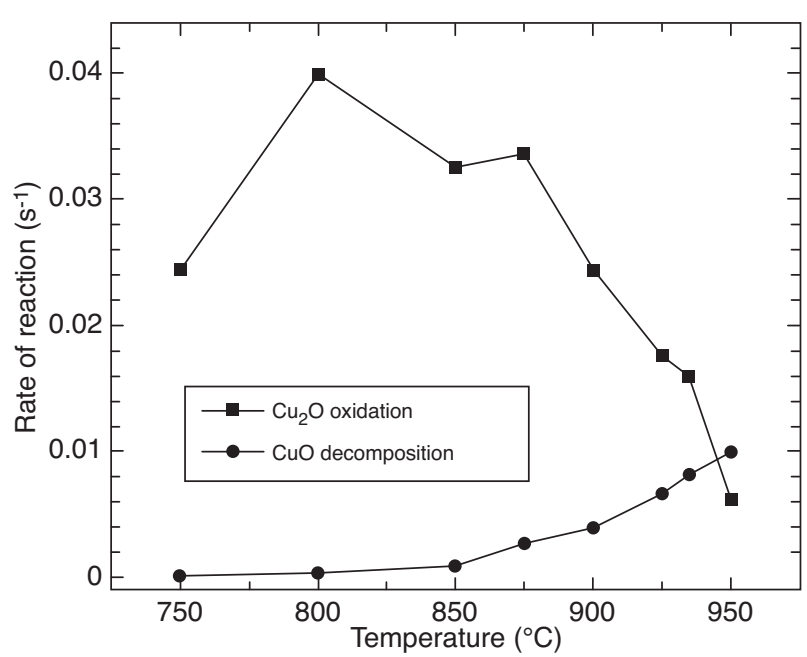

Figure 9

Plot of rate constants $v s$ temperature for the oxidation of $\mathrm{Cu}_{2} \mathrm{O}$ and the decomposition of $\mathrm{CuO}$. 
of $\mathrm{CuO}$ over a temperature range of 760 to $910^{\circ} \mathrm{C}$, for oxides produced from copper of similar size to those in the current study [28]. The activation energy for their first order fit of the data of $322 \mathrm{~kJ} / \mathrm{mol}$ is very close to the value of $327 \mathrm{~kJ} / \mathrm{mol}$ obtained in this study. However, the current rates are somewhat faster with a preexponential of $1.488 \times 10^{14}$ compared to their value of $1.595 \times 10^{13}$. Their oxidation data were obtained at temperatures under $550^{\circ} \mathrm{C}$ and are strictly not comparable. The data of Garcia-Labiano et al. [13] of oxidation of an oxygen carrier of $10 \% \mathrm{CuO}$ on an $\mathrm{Al}_{2} \mathrm{O}_{3}$ substrate at temperatures of 500 to $800^{\circ} \mathrm{C}$ in air are also relevant. The oxidation time at their maximum temperature of $800^{\circ} \mathrm{C}$ is $8 \mathrm{~s}$, a factor of about 20 smaller than the oxidation time in the present study at the same temperature. This large difference is probably a consequence of the very thin coating of the $\mathrm{CuO}$, which was estimated to be $0.4 \mathrm{~nm}$ [13]. This thin coating, planar in nature results in a reaction rate $(\mathrm{d} \alpha / \mathrm{d} t)$, that is independent of time or conversion [13].

\section{MASS LOADING OF THE OXYGEN CARRIER}

The masses of the oxygen-carrier in the fuel and air reactors are calculated here for an assumed plug flow of the solid. This assumption simplifies the analysis and provides a lower limit for the loading. It is approximated in practice by the use of multiple reactors, one of the options proposed in [3] or that has been adopted in a pilot reactor [25]. The reaction order with respect to the reactant was assumed to be first order, an approximation to the data as shown in Figures 7 and 8 . Temperatures that minimize the oxygen carrier were also selected. A temperature of $950^{\circ} \mathrm{C}$ was selected to approximate the highest temperatures used in laboratory reactors with solid fuels without bed agglomeration and attrition [2-8, 11]. A temperature of $850^{\circ} \mathrm{C}$ was used in the air reactor, a temperature a little higher than the peak rate of oxidation found at around $800^{\circ} \mathrm{C}$ in the present study (Fig. 9).

The residence time of a plug-flow reactor for the cupric oxide decomposition from an inlet concentration of $X_{\mathrm{CuO}, A R}$ to an exit concentration of $X_{\mathrm{CuO}, F R}$ is given by:

$$
\tau_{F R}=\frac{1}{k_{r, \mathrm{CuO}}} \ln \left[\frac{1}{\left\{1-\left(\frac{\Delta X_{S}}{X_{\mathrm{CuO}, A R}}\right)\right\}}\right]
$$

where $k_{r, \mathrm{CuO}}$ is a first order decomposition rate constant $\left(\mathrm{s}^{-1}\right)$ given in Figure 9.

The residence time of a plug-flow reactor for oxidation from an inlet concentration of $\left(1-X_{\mathrm{CuO}, F R}\right)$ to an exit concentration of $\left(1-X_{\mathrm{CuO}, A R}\right)$ is given by:

$$
\tau_{A R}=\frac{1}{k_{r, \mathrm{Cu}_{2} \mathrm{O}}} \ln \left[\frac{1}{\left\{1-\left(\frac{\Delta X_{S}}{\left(1-X_{\mathrm{CuO}, F R}\right)}\right)\right\}}\right]
$$

where $k_{r, \mathrm{Cu}_{2} \mathrm{O}}$ is pseudo first order oxidation rate constant $\left(\mathrm{s}^{-1}\right)$ reported for oxidation in air in Figure 9. The pseudo first order rate constant was adjusted from a rate for $21 \%$ oxygen to one at the log mean concentration of an inlet oxygen concentration of $21 \%$ and exit concentration of 3\%; in making the adjustment, a square root dependence on oxygen partial pressure was assumed consistent with preliminary TGA oxidation results with different oxygen concentrations.

The mass of $\mathrm{Cu}$ metal required per $\mathrm{MW}_{\mathrm{t}}$ of carbonaceous fuel burnt in a CLOU system, can be obtained from Equation (8):

$$
m_{\mathrm{Cu}}=\dot{m}_{\mathrm{Cu}}\left(\tau_{F R}+\tau_{A R}\right) \mid \Delta X_{S}, X_{\mathrm{CuO}, F R}
$$

where the residence times are determined by Equations (6) and (7) as a function of $X_{\mathrm{CuO}, A R}$ and $X_{\mathrm{CuO}, F R}$, or, alternatively $X_{\mathrm{CuO}, F R}$ and $\Delta X_{S}$. The resulting mass of the copper in the oxygen carrier per $\mathrm{MW}_{\mathrm{t}}$ input of fuel is provided in Figure 10, mapping similar to those developed previously $[13,15]$.

The results in Figure 10 show a minimum carrier loading at a specific $X_{\mathrm{CuO}, F R}$ for each value of $\Delta X_{S}$, starting with a minimum of $125 \mathrm{~kg} / \mathrm{MW}_{\mathrm{t}}$ at an $X_{\mathrm{CuO}, F R}$ of 0.5 and at a $\Delta X_{S}$ of 0.05 , shifting to lower values of $X_{\mathrm{CuO}, F R}$ as $\Delta X_{S}$ increases. For the highest $\Delta X_{S}$ shown on the plot, 0.65 , the minimum carrier loading is $150 \mathrm{~kg} / \mathrm{MW}_{\mathrm{t}}$. The shape of each curve is determined by the increase in reaction time in the fuel reactor as the value of $X_{\mathrm{CuO}, F R}$ decreases at a given $\Delta X_{S}$ because of the first order rate equation (see Eq. 6). The reaction times for the air reactor by contrast increase with increasing $X_{\mathrm{CuO}, F R}$ at a fixed $\Delta X_{S}$ (see Eq.7). Selection of the optimum values of conditions depends on selecting a high value of $\Delta X_{S}$ to reduce the circulation rate of oxygen carrier (see Fig. 3) as

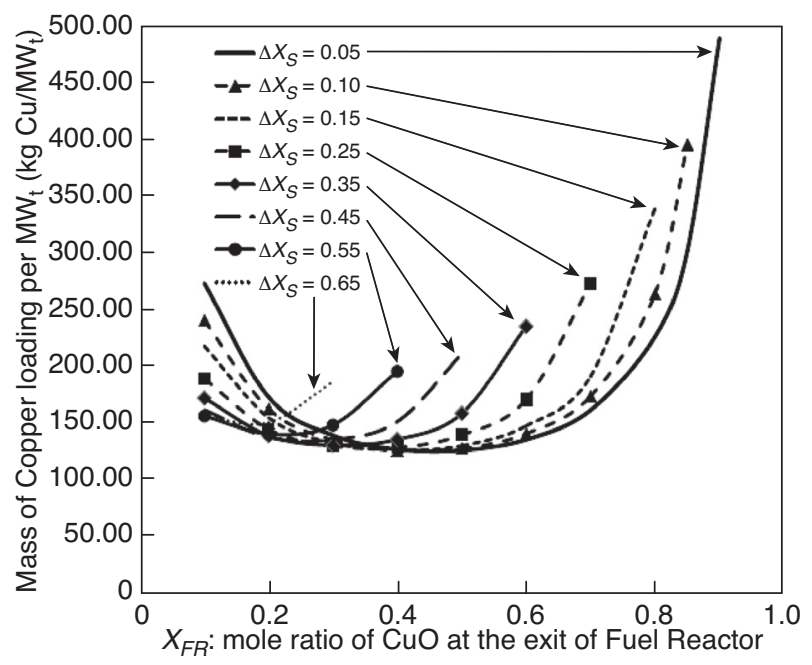

Figure 10

Mass of copper loading per $\mathrm{MW}_{\mathrm{t}} v s$ mole ratio of $\mathrm{CuO}$ at the exit of fuel reactor for different values of $\Delta X_{S}$. 
well as minimize oxygen carrier loading. An optimization would be based on an economic analysis. $\Delta X_{S}$ between 0.2-0.4 has been cited for low circulation rates and low solids inventories [15]. Values of $X_{\mathrm{CuO}, F R}=0.3$ and $\Delta X_{S}$ of 0.45 have been chosen as a basis to perform an order of magnitude calculation, at which copper loading in the oxygen carrier is $135 \mathrm{~kg} \mathrm{CuO} / \mathrm{MW}_{\mathrm{t}}$. Previous work has shown a minimum solids loading of approximately $13.3 \mathrm{~kg} \mathrm{CuO} / \mathrm{MW}_{\mathrm{t}}$ for combustion of methane and a $10 \% \mathrm{Cu}$ on an aluminium support [13], less than $1200 \mathrm{~kg} \mathrm{Fe}{ }_{2} \mathrm{O}_{3} / \mathrm{MW}_{\mathrm{t}}$ for combustion of petcoke with a $60 \% \mathrm{Fe}_{2} \mathrm{O}_{3} / 40 \% \mathrm{MgAlO}_{4}$ oxygen-carrier [8] and 48 to $80 \mathrm{~kg} \mathrm{CuO} / \mathrm{MW}_{\mathrm{t}}$ for combustion of petroleum coke for a $40 \% \mathrm{CuO} / \mathrm{ZrO}_{2}$ oxygen carrier operated in a CLOU mode [5]. All solid loadings are reported on a support-free basis.

\section{CARBON LOADING AND OXYGEN PARTIAL PRESSURE IN THE FUEL REACTOR}

Calculation of the carbon burnout needs to be addressed simultaneously with the estimation of the bulk oxygen concentration in the fuel reactor, which is determined by the oxygen release by the oxygen carrier, the oxygen consumption by the carbon, and the net transfer of oxygen to the effluent gases and in the streams to and from the fuel reactor. The major terms that will be considered in this section are the rate of production of oxygen by the oxygen carrier and the oxidation of carbon in the fuel reactor.

\subsection{Rate of Net Oxygen Release by Oxygen Carrier}

The kinetics of the reaction $4 \mathrm{CuO} \rightarrow 2 \mathrm{Cu}_{2} \mathrm{O}+\mathrm{O}_{2}$ are considered below. The rate of oxygen release from $\mathrm{CuO}$ can be expressed utilizing the relationship:

$$
r_{\mathrm{O}_{2}, \mathrm{CuO}}=\frac{k_{r, \mathrm{CuO}}[\mathrm{CuO}]}{4}-\frac{k_{r, \mathrm{Cu}_{2} \mathrm{O}}\left[\mathrm{Cu}_{2} \mathrm{O}\right] \rho_{\mathrm{O}_{2}}^{1 / 2}}{2}
$$

When the reaction is governed by equilibrium the surface concentration of $\mathrm{O}_{2}$ at the surface of the $\mathrm{CuO} / \mathrm{Cu}_{2} \mathrm{O}$ particle is $\rho_{\mathrm{O}_{2, e}}$; at the opposite extreme, the reverse reaction in Equation (9) can be neglected. The analysis in the subsequent section has been conducted when the $\mathrm{CuO} / \mathrm{Cu}_{2} \mathrm{O}$ reaction is close to equilibrium which is relevant to the conditions in this paper.

Under the conditions of mass transfer control, the molar rate of oxygen mass transfer from $\mathrm{CuO}$ particles in a fuel reactor is then given by:

$$
\dot{N}_{\mathrm{O}_{2}, \mathrm{CuO}}=k_{m, \mathrm{CuO}} A_{\mathrm{CuO}}\left(\frac{\rho_{\mathrm{O}_{2, e}}}{R T}-\frac{\rho_{\mathrm{O}_{2, b}}}{R T}\right)\left(\left(\frac{\sigma_{P, \mathrm{CuO}}}{V_{R}}\right) V_{R}\right)
$$

\subsection{Rate of Carbon Oxidation}

The relation between the surface oxygen partial pressure on a carbon particle and the bulk oxygen partial pressure around the particle is obtained by equating the mass rate of oxygen transfer from bulk environment to the surface of the carbon particle and the mass consumption of oxygen at the surface of the carbon particle as shown below:

$$
k_{m, \mathrm{C}} A_{\mathrm{C}}\left(\left(m w_{\mathrm{C}}\right)\right)\left(\frac{\rho_{\mathrm{O}_{2, b}}}{R T}-\frac{\rho_{\mathrm{O}_{2, s}}}{R T}\right)=k_{r, \mathrm{C}} A_{\mathrm{C}} \rho_{\mathrm{O}_{2, s}} \frac{1}{2}
$$

where $k_{r, C}$ is a reaction rate constant for carbon oxidation $\left(\mathrm{g} / \mathrm{cm}^{2}(\mathrm{~atm})^{0.5} \mathrm{~s}\right)$. This equation can be solved for $\rho_{\mathrm{O}_{2, S}}$.

The molar rate of oxygen mass transfer to the surface of carbon particles in a fuel reactor can be expressed as:

$$
\dot{N}_{\mathrm{O}_{2}, \mathrm{C}}=k_{m, C} A_{C}\left(\frac{\rho_{\mathrm{O}_{2 b}}}{R T}-\frac{\rho_{\mathrm{O}_{2, s}}}{R T}\right)\left(\left(\frac{\sigma_{P, C}}{V_{R}}\right) V_{R}\right)
$$

where the mass transfer coefficient is calculated assuming a Sherwood Number of 2 and obtaining the diffusivity of oxygen in carbon-dioxide using Fuller's correlation [31].

\subsection{Calculation of Bulk Oxygen Concentration}

The bulk oxygen concentration can be obtained by equating the molar rate of oxygen release from the $\mathrm{CuO}$ particles to the mass transfer to the carbon surface; that is, equating the right hand sides of Equations (10) and (12):

$$
\left(\rho_{\mathrm{O}_{2, e}}-\rho_{\mathrm{O}_{2, b}}\right)=\left(\frac{k_{m, \mathrm{C}} A_{\mathrm{C}}}{k_{m, \mathrm{CuO}} A_{\mathrm{CuO}}}\right)\left[\frac{\frac{\sigma_{P, \mathrm{C}}}{V_{R}}}{\frac{\sigma_{P, \mathrm{CuO}}}{V_{R}}}\right]\left(\rho_{\mathrm{O}_{2, b}}-\rho_{\mathrm{O}_{2, s}}\right)
$$

The following assumptions have been made in developing Equation (13):

- it is assumed that the partial pressure of $\mathrm{O}_{2}$ at the surface of the $\mathrm{CuO}$ particle is at equilibrium. In this study the case of mass transfer of $\mathrm{O}_{2}$ from the $\mathrm{CuO}$ particle is assumed to be rate controlling as a first approximation for design. The case of $\mathrm{O}_{2}$ decomposition from $\mathrm{CuO}$ being controlled by chemical reaction will be addressed in a future publication;

- the effect of chemical reaction of the carbon is included by using the empirical fit of data on carbon burnout based on its external surface area developed by Hurt and Mitchell [32].

Equation (13) can be simplified to yield an expression in surface oxygen partial pressure, $\rho_{\mathrm{O}_{2, S}}$ which is:

$$
\rho_{\mathrm{O}_{2, s}}=\frac{\left((\lambda+1) \rho_{\mathrm{O}_{2, b}}-\rho_{\mathrm{O}_{2, e}}\right)}{\lambda}
$$

where:

$$
\lambda=\left(\frac{k_{m, \mathrm{C}} A_{\mathrm{C}}}{k_{m, \mathrm{CuO}} A_{\mathrm{CuO}}}\right)\left[\frac{\frac{\sigma_{P, \mathrm{C}}}{V_{R}}}{\frac{\sigma_{P, \mathrm{CuO}}}{V_{R}}}\right]
$$


By equating the surface oxygen partial pressures which are obtained from Equations (11) and (14), Equation (16) is obtained:

$$
\begin{aligned}
& \frac{2}{\lambda} \rho_{\mathrm{O}_{2, b}}+\left(\frac{k_{r, \mathrm{C}} R T}{k_{m, \mathrm{C}}\left(m w_{\mathrm{C}}\right)}\right)\left[4 \rho_{\mathrm{O}_{2, b}}+\left(\frac{k_{r, \mathrm{C}} R T}{k_{m, \mathrm{C}}\left(m w_{\mathrm{C}}\right)}\right)^{2}\right]^{\frac{1}{2}} \\
& -\frac{2}{\lambda} \rho_{\mathrm{O}_{2, e}}-\left(\frac{k_{r, \mathrm{C}} R T}{k_{m, \mathrm{C}}\left(m w_{\mathrm{C}}\right)}\right)^{2}=0
\end{aligned}
$$

This equation can be solved to obtain the bulk oxygen concentration as a function of two coefficients, $\lambda$, which provides a measure of the ratio of loadings of carbon to $\mathrm{CuO}$, and:

$$
\left(\frac{k_{r, \mathrm{C}} R T}{k_{m, \mathrm{C}}\left(m w_{\mathrm{C}}\right)}\right)
$$

which provides a measure of the ratio of reaction rate to the mass transfer coefficient for the carbon. The equation was solved for the bulk oxygen concentration for two US coals, Pittsburgh\#8 and Pocahontas [32], and an Australian brown coal [33]. A coal particle size of $115 \mu \mathrm{m}$ and a $\mathrm{CuO}$ particle size of $100 \mu \mathrm{m}$ were assumed. An equilibrium $\mathrm{O}_{2}$ concentration of $4.5 \%$, corresponding to a temperature of $950^{\circ} \mathrm{C}$ for the oxygen carrier, was also used for the calculation. The results for the bulk $\mathrm{O}_{2}$ concentration, presented in Figure 11, shows a decrease in bulk concentration as the carbon loading relative to that of the $\mathrm{CuO}$ increases. This trend is consistent with the data in Figure 1 where the $\mathrm{O}_{2}$ concentration decreased rapidly as the $\mathrm{O} / \mathrm{Cu}$ ratio decreased to 0.8 (40\% decomposition of the $\mathrm{CuO}$ ) while only $10 \%$ of the carbon was consumed [2].

If the carbon particles are assumed to burn in a shrinking sphere mode, the time for complete burnout of the carbon can

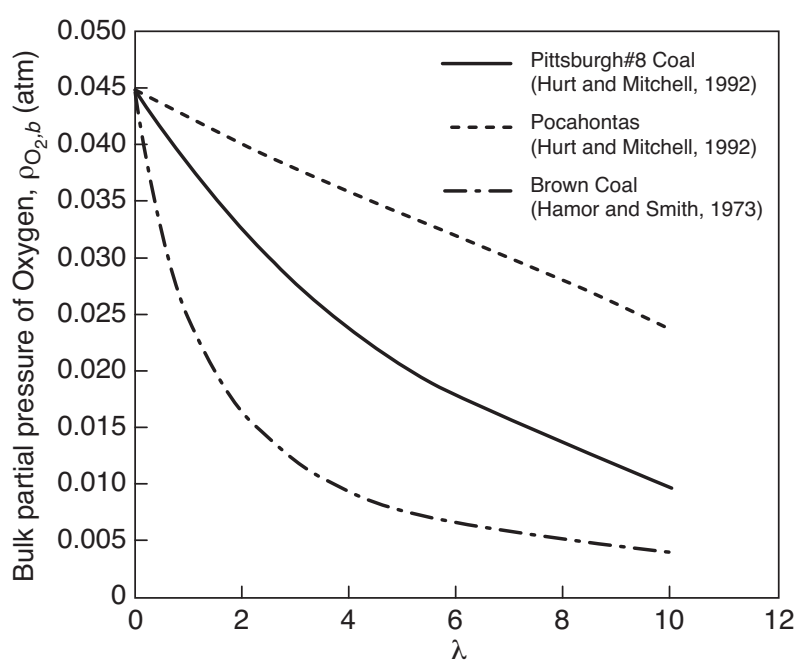

Figure 11

Bulk oxygen partial pressure $v s \lambda$ (see $E q .16$ ) at $950^{\circ} \mathrm{C}$.

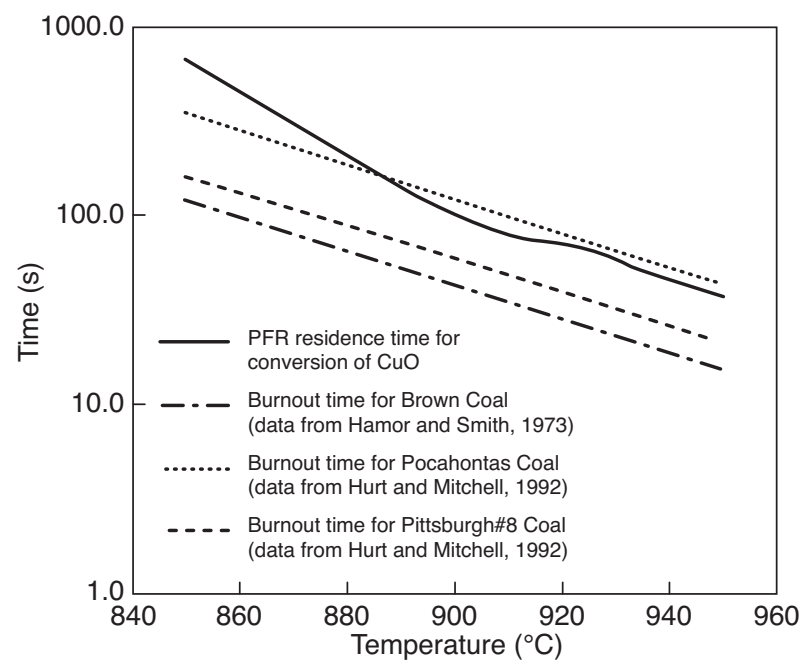

Figure 12

Calculated times $v s$ temperature in the Fuel Reactor for $\mathrm{CuO}$ decomposition and the burnout of three coals: an Australian brown, a Pocahontas and a Pittsburgh\#8.

be calculated, assuming the combustion time will depend on the bulk oxygen concentration. The bulk concentration for the conditions selected for the test case is close to equilibrium since the maximum value of $\lambda$ for the values of coal feed and $\mathrm{CuO}$ circulation was found to be 0.17 . The burnout times were calculated for the three coals and are compared in Figure 12 with the conversion times for the cupric oxide in the fuel reactor calculated using Equation (6). Complete conversion is found for the three coals except for the Pocahontas coal at high temperatures. For the Pocahontas coal the times for burnout are seen to exceed the cupric oxide reduction times at temperatures above $1160 \mathrm{~K}\left(\sim 890^{\circ} \mathrm{C}\right)$. The difference however is small and the carbon burnout is found to be greater than $99 \%$.

\section{CONCLUSIONS}

CLOU utilizing $\mathrm{CuO}$ as an oxygen carrier shows major potential for the oxidation of solid fuels. In particular, the gasification rate of carbon is no longer a major constraint in the sizing of the fuel reactor as the burnout times for carbon are comparable or smaller than the decomposition times of the $\mathrm{CuO}$. A limiting expression has been developed which can be used to determine the departure from equilibrium of the bulk oxygen partial pressure in the fuel reactor as a function of fuel loading for the case in which the rate of oxygen release is mass transfer controlled, which is the case in the present analysis. The air reactor volume is greater than the fuel reactor because of the low oxidation rates of $\mathrm{Cu}_{2} \mathrm{O}$ which is controlled by diffusion through the $\mathrm{CuO}$ product layer; a limitation that can be 
mitigated in part by the use of supported $\mathrm{CuO}$ [13]. In contrast with CLC systems, the energy release between the fuel and air reactor were of the same order because of the high heat of combustion of the carbon fuel. Estimates of the optimum conditions for the conversion of the fuel reactor and air reactor were around values of $X_{\mathrm{CuO}, F R}=0.3$ and $X_{\mathrm{CuO}, A R}=0.75$. At these conditions the residence times in the air and fuel reactor were about equal. The value of the oxygen carrier mass loading at these conditions is $135 \mathrm{~kg} \mathrm{CuO} / \mathrm{MW}_{\mathrm{t}}$. This value is higher than value reported for CLC systems burning gaseous fuels, lower than the combustion of solids burned in a CLC mode and a little higher than other studies on the use of $\mathrm{CLOU}$ with $\mathrm{CuO}$ supported on $\mathrm{ZrO}_{2}$. It should be noted that the values in this paper are for ideal reactors and do not include the resistances to the gas-solid contacting in real reactors [19].

\section{ACKNOWLEDGMENTS}

This material is based upon work supported by the Department of Energy under Award Number DE-NT0005015. We are grateful to Prof. Terry A. Ring, Department of Chemical Engineering, University of Utah and to Blake Wilde, Kevin Tucker and Yongbing Pei, students at the University of Utah for their support. The authors were inspired in their studies of CLOU by the research at Chalmers University of Prof. Anders Lyngfelt, Dr. Tobias Mattisson and Dr. Henrik Leion.

\section{REFERENCES}

1 Lyngfelt A., Oxygen Carriers for chemical-looping combustion - $4000 \mathrm{~h}$ of operational experience, Oil Gas Sci. Technol., to be published.

2 Lewis W.K., Gilliland E.R., Sweeney W.P. (1951) Gasification of Carbon Metal Oxides in a Fluidized Powder Bed, Chem. Eng. Prog. 47, 5, 251-256.

3 Lewis W.K., Gilliland E.R. (1954) US Patent 2,665,972, January 12 .

4 Mattisson T., Lyngfelt A., Leion H. (2009) Chemical-looping with oxygen uncoupling for combustion of solid fuels, Int. J. Greenhouse Gas Control 3, 11-19.

5 Mattisson T., Leion H., Lyngfelt A. (2009) Chemical-looping with oxygen uncoupling using $\mathrm{CuO} / \mathrm{ZrO}_{2}$ with petroleum coke, Fuel 88, 683-690.

6 Leion H., Mattisson T., Lyngfelt A. (2008) Solid fuels in chemical looping combustion, Int. J. Greenhouse Gas Control 2, 180-193.

7 Leion H., Mattisson T., Lyngfelt A. (2008) Combustion of a German lignite using chemical-looping with oxygen uncoupling (CLOU), The Clearwater Coal Conference - The 33rd International Technical Conference on Coal Utilization \& Fuel Systems, Clearwater, Florida.

8 Leion H., Mattisson T., Lyngfelt A. (2007) The use of petroleum coke as a fuel in chemical-looping combustion, Fuel $\mathbf{8 6}$, 1947-1958.
9 De Diego L.F., Garcia-Labiano F., Adanez J., Gayan P., Abad A., Corbella B.M., Palacios J.M. (2004) Development of $\mathrm{Cu}-$ based oxygen carriers for chemical-looping combustion, Fuel $\mathbf{8 3}$, $13,1749-1757$.

10 Adanez J., de Diego L.F., Garcia-Labiano F., Gayan P., Abad A., Palacios J.M. (2004) Selection of oxygen carriers for chemicallooping combustion, Energ. Fuel. 18, 2, 371-377.

11 De Diego L.F., Gayan P., Garcia-Labiano F., Celaya J., Abad M., Adanez J. (2005) Impregnated $\mathrm{CuO} / \mathrm{Al}_{2} \mathrm{O}_{3}$ oxygen carriers for chemical-looping combustion: Avoiding fluidized bed agglomeration, Energ. Fuel. 19, 5, 1850-1856.

12 Corbella B.M., De Diego L., Garcia F., Adanez J., Palacios J.M. (2005) The performance in a fixed bed reactor of copper-based oxides on titania as oxygen carriers for chemical looping combustion of methane, Energ. Fuel. 19, 2, 433-441.

13 Garcia-Labiano F., de Diego L.F., Adanez J., Abad A., Gayan P. (2004) Reduction and Oxidation kinetics of copper-based oxygen carrier prepared by impregnation for chemical-looping combustion, Ind. Eng. Chem. Res. 43, 26, 8168-8177.

14 Garcia-Labiano F., Adanez J., de Diego L.F., Gayan P., Abad A. (2006) Effect of pressure on the behavior of copper-, iron-, and nickel-based oxygen carriers for chemical-looping combustion, Energ. Fuel. 20, 1, 26-33.

15 Abad A., Adanez J., Garcia-Labiano F., de Diego L.F., Gayan P., Celaya J. (2007) Mapping of the range of operational conditions for $\mathrm{Cu}-, \mathrm{Fe}-$, and Ni-based oxygen carriers in chemical-looping combustion, Chem. Eng. Sci. 62, 533-549.

16 Forero C.F., Gayan P., de Diego L.F., Abad A., Garcia-Labiano F., Adanez J. (2009) Syngas combustion in a 500 Wth ChemicalLooping Combustion system using an impregnated $\mathrm{Cu}$-based oxygen carrier, Fuel Process. Technol. 90, 12, 1471-1479.

17 Adanez J., Gayan P., Celaya J., de Diego L.F., Garcia-Labiano F., Abad A. (2006) Chemical looping combustion in a $10 \mathrm{~kW}$ (th) prototype using a $\mathrm{CuO} / \mathrm{Al}_{2} \mathrm{O}_{3}$ oxygen carrier: Effect of operating conditions on methane combustion, Ind. Eng. Chem. Res. 45, 17, 6075-6080.

18 De Diego L.F., Garcia-Labiano F., Gayan P., Celaya J., Palacios J.M., Adanez J. (2007) Operation of a $10 \mathrm{kWth}$ chemical-looping combustor during $200 \mathrm{~h}$ with a $\mathrm{CuO}-\mathrm{Al}_{2} \mathrm{O}_{3}$ oxygen carrier, Fuel 86, 7-8, 1036-1045.

19 Abad A., Adanez J., Garcia-Labiano F., de Diego L.F., Gayan P. (2010) Modeling of the chemical-looping combustion of methane using a $\mathrm{Cu}$-based oxygen-carrier, Combust. Flame 157, 3, 602-615.

20 Garcia-Labiano F., Gayan P., Adanez J., De Diego L.F., Forero C.R. (2007) Solid waste management of a chemical-looping combustion plant using Cu-based oxygen carriers, Environ. Sci. Technol. 41, 16, 5882-5887.

21 Dennis J.S., Müller C.R., Scott S.A. (2010) In situ gasification and $\mathrm{CO}_{2}$ separation using chemical looping with a $\mathrm{Cu}$-based oxygen carrier: Performance with bituminous coals, Fuel 89, 2353-2364.

22 Siriwardane R., Tian H., Miller D., Richards G., Simonyi T., Poston J. (2010) Evaluation of reaction mechanism of coal-metal oxide interactions in chemical-looping combustion, Combust. Flame 157, 11, 2198-2208.

23 Siriwardane R., Tian H., Richards G., Simonyi T., Postoni J. (2009) Chemical-looping combustion of coal with metal oxide oxygen carriers, Energ. Fuel. 23, 3885-3892.

24 Li. F., Kim H., Sridhar D., Zeng L., Wang F., Tong A., Fan L.-S. (2009) Coal Direct Chemical Looping (CDCL) process for hydrogen and power generation, The Clearwater Coal Conference - The 34th International Technical Conference on Coal Utilization \& Fuel Systems, Clearwater, Florida. 
25 Berguerand N., Lyngfelt A. (2010) Batch Testing of Solid Fuels with Ilmenite in a $10 \mathrm{~kW}_{\text {th }}$ Chemical-Looping Combustor, Fuel 89, 1749-1762.

26 Berguerand N. (2007) Design and operation of a $10 \mathrm{~kW}_{\text {th }}$ chemicallooping combustor for solid fuels, $P h D$ Thesis, Department of Energy and Environment, Chalmers University of Technology, Göteborg, Sweden.

27 Lyngfelt A., Leckner B., Mattison T. (2001) A fluidized-bed combustion process with inherent $\mathrm{CO}_{2}$ separation: application of chemical-looping combustion, Chem. Eng. Sci. 56, 3101-3113.

28 Chadda D., Ford J.D., Fahim M.A. (1989) Chemical Energy Storage by the reaction cycle $\mathrm{CuO} / \mathrm{Cu}_{2} \mathrm{O}$, Int. J. Energ. Res. 13, 63-73.

29 Prisedsky V.V., Vinogradov V.M. (2004) Fragmentation of diffusion zone in high-temperature oxidation of copper, J. Solid State Chem. 177, 4258-4268.
30 Zhu Y., Mimura K., Isshiki M. (2004) Oxidation Mechanism of $\mathrm{Cu}_{2} \mathrm{O}$ to $\mathrm{CuO}$ at $600-1050^{\circ} \mathrm{C}$, Oxid. Met. 62, 3-4.

31 Poling B.E., Prausnitz J.M., O'Connell J.P. (2001) The Properties of Gases and Liquids, 5th ed., Mc-Graw Hill, New York.

32 Hurt R.F., Mitchell R.E. (1992) Unified High-Temperature Char Combustion Kinetics for a suite of coals of various rank, 24th International Symposium on Combustion, pp. 1243-1250.

33 Hamor R.J., Smith I.W., Tyler R.J. (1973) Kinetics of Combustion of a Pulverized Brown Coal Char between 630 and 2200 K, Combust. Flame 21, 2, 153-162.

Final manuscript received in November 2010 Published online in April 2011 or distributed for profit or commercial advantage and that copies bear this notice and the full citation on the first page. Copyrights for components of this work owned by others than IFP Energies nouvelles must be honored. Abstracting with credit is permitted. To copy otherwise, to republish, to post on servers, or to redistribute to lists, requires prior specific permission and/or a fee: Request permission from Information Mission, IFP Energies nouvelles, fax.+33147527096, or revueogst@ifpen.fr. 